\title{
Keanekaragaman Jenis Ikan di Sepanjang Sungai Opak Propinsi Daerah Istimewa Yogyakarta, Indonesia
}

\section{The Diversity Of Fishes Along Opak River Province Of Daerah Istimewa Yogyakarta, Indonesia}

\author{
Donan Satria Yudha ${ }^{*}$, Trijoko', Rury Eprilurahman ${ }^{1}$, Rizki Nugraha ${ }^{1}$, Rosita Dwi \\ Putri Suranto $^{1}$, Farahsani Umi Abida ${ }^{1}$, Vega Felicia Tobing ${ }^{1}$, Raden Firly Fathiya ${ }^{1}$, Sri \\ Nopitasari ${ }^{1}$
}

\author{
${ }^{1}$ Laboratorium Sistematika Hewan, Fakultas Biologi, Universitas Gadjah Mada \\ Jl. Teknika Selatan Sekip Utara, Sleman, Daerah Istimewa Yogyakarta, Indonesia \\ Email:donan_satria@ugm.ac.id_*Penulis Korespondensi
}

\begin{abstract}
The researches regarding the diversity of freshwater fishes in the Opak River, Province of DIY has been published in 2006, 2011 and 2013. Publication in 2006 focused to study the fishes diversity on upstream and midstream; in 2011 on upstream; and in 2013 on downstream. Data regarding the diversity of fishes along Opak River need to be completed, especially comprehensive data from upstream to downstream and estuary. The additional data is necessary because there is possibility that there were some species that has not been caught during previous research. The aim of the research was to complement and to add data about the diversity of fishes along Opak River from upstream to estuary in the Province of DIY. Samples were collected using Purposive Random Sampling methods with fishnets. Sampling area generally divided into four locations i.e., upstream, midstream, downstream and estuary. Result there were species of fishes which not found on previous research, i.e., five species found only on the upstream of our research, three species found on midstream of our research which not found on upstream and downstream of previous research, seven species were found on downstream and fifteen species found on estuary and were not found on downstream of previous research. There are 28 species of fishes found in our research which not found in previous research.
\end{abstract}

Keywords: diversity, fish, new data, additional data, the Opak River, Yogyakarta

\begin{abstract}
Abstrak
Penelitian mengenai keanekaragaman ikan air tawar di Sungai Opak DIY telah dilakukan dan dipublikasikan, tahun 2006, 2011 dan 2013. Data mengenai keanekaragaman ikan di Sungai Opak perlu dilakukan penambahan data, terutama data menyeluruh dari hulu hingga muara. Penambahan data perlu dilakukan, karena dimungkinkan ditemukan jenis ikan yang belum sempat tertangkap pada penelitian sebelumnya. Data jenis ikan yang tidak tertangkap pada penelitian sebelumnya, dapat menambah keanekaragaman jenis ikan di Sungai Opak. Penelitian ini bertujuan untuk melengkapi dan menambah data keanekaragaman jenis ikan yang terdapat di sepanjang Sungai Opak, dari hulu hingga muara. Pengambilan sampel dari hulu hingga muara menggunakan metode Purposive Random Sampling dengan bantuan jaring besar, kecil dan jala tebar. Sampling secara umum dibagi dalam empat bagian yaitu: hulu, tengah, hilir dan muara. Pada penelitian yang kami lakukan, terdapat beberapa jenis ikan yang tidak dijumpai pada penelitian sebelumnya, yaitu: lima jenis ikan dibagian hulu, di bagian tengah terdapat tiga jenis ikan yang tidak dijumpai pada penelitian sebelumnya, baik sampling hulu maupun hilir. Di bagian hilir dijumpai tujuh jenis ikan saat penelitian ini dan tidak dijumpai pada penelitian sebelumnya. Pada bagian muara, dijumpai lima belas jenis ikan yang tidak dijumpai di hilir pada penelitian sebelumnya. Total terdapat 28 jenis ikan yang dijumpai di tahun 2013 tetapi belum dijumpai di penelitian sebelumnya.
\end{abstract}

Kata kunci : keanekaragaman, ikan, data baru, tambahan data, Sungai Opak, Yogyakarta 


\section{Pendahuluan}

Penelitian mengenai keanekaragaman ikan Sungai Opak DIY telah dipublikasikan, diantaranya oleh Trijoko dan Pranoto (2006) di hulu sampai tengah Sungai Opak; Djumanto dan Probosunu (2011) di hulu Sungai Opak; Djumanto, dkk (2013) di hilir Sungai Opak. Data mengenai keanekaragaman ikan di Sungai Opak perlu dilakukan penambahan data, terutama data menyeluruh dari hulu hingga muara. Pembaruan data perlu dilakukan, karena dimungkinkan ditemukan jenis ikan yang belum sempat tertangkap pada penelitian sebelumnya, maupun jenis ikan di muara Sungai Opak. Penambahan data, terutama di bagian muara, dapat menambah keanekaragaman jenis ikan di Sungai Opak. Penelitian menyeluruh dalam satu kegiatan, dari hulu hingga muara Sungai Opak perlu dilakukan, agar dapat diketahui data keanekaragaman ikan secara menyeluruh.

Pada penelitian yang dilakukan oleh Djumanto \& Probosunu (2011) dibagian hulu Sungai Opak, didapatkan 10 jenis ikan. Lokasi penelitian mereka lakukan di kecamatan yang sama dengan yang kami lakukan, tetapi tidak diketahui lokasi dusun dan desanya. Penelitian yang kami lakukan di hulu, berlokasi di 5 desa (Tabel 1). Penelitian oleh Djumanto, dkk (2013) dibagian hilir Sungai Opak, didapatkan 34 jenis ikan. Lokasi penelitian yang kami lakukan, dibagi menjadi 4 bagian, yaitu hulu, tengah, hilir dan muara. Bagian tengah sungai, adalah aliran yang melewati wilayah padat aktivitas manusia seperti di sisi utara dan selatan Candi Prambanan. Muara Sungai Opak belum terdata, sehingga kami tambahkan lokasi muara dalam penelitian ini.

Penelitian ini bertujuan untuk keanekaragaman jenis ikan yang terdapat di sepanjang Sungai Opak Propinsi Daerah Istimewa Yogyakarta (DIY). Keanekaragaman tersebut berguna untuk memberikan informasi lebih mengenai jenis-jenis alami dan introduksi serta sebagai database yang dapat dijadikan acuan bagi penelitian selanjutnya.

\section{Metode Penelitian}

Spesimen yang dipelajari adalah semua spesies ikan air tawar yang dijumpai di Sungai
Opak dari hulu hingga muara sungai di Propinsi DIY. Bahan kimia (etanol 70\%, formaldehid 4\%, akuades dan kloroform) untuk pembuatan awetan spesimen basah.

Penelitian dilakukan selama bulan Mei hingga November 2013. Lokasi penelitian sepanjang Sungai Opak dari Hulu hingga Muara Sungai (Pantai Depok). Metode yang digunakan adalah Purposive Random Sampling dengan bantuan jaring kecil, besar dan jala tebar. Pada bagian Hulu hingga Hilir Sungai Opak ditentukan masing-masing 5 titik sampling (Tabel 1). Setiap titik sampling memiliki panjang $500 \mathrm{~m}$. Total panjang sungai lokasi kajian masing-masing bagian hulu, tengah dan hilir tidak termasuk muara adalah $2,5 \mathrm{~km}$. Pada masing-masing titik sampling ditentukan bagian air yang dimungkinkan banyak terdapat ikan, yaitu di bagian pool, rapid, tepi dan bebatuan/cerukan. Sampling dilakukan dalam dua waktu yang berbeda yaitu siang hari (untuk menemukan jenis yang beraktivitas diurnal) dan malam hari (untuk menemukan jenis yang beraktivitas nokturnal).

Semua spesimen ikan ditangkap, diidentifikasi dan didokumentasi. Diambil specimen voucher untuk diawetkan dengan etanol $70 \%$ dan diberi label. Identifikasi ikan beserta jenis-jenis ikan alami dan introduksi berdasar Kottelat et al, (1993) dengan revisi nama spesies ikan beserta klasifikasi taksonominya berdasarkan Kottelat (2013) dan Nelson, et al, (2016). Guna mengetahui jenisjenis ikan perairan sungai yang dikonsumsi, dilakukan wawancara kepada pemancing dan penjala ikan yang ditemui saat sampling maupun penduduk yang bertempat tinggal di sekitar lokasi kajian.

\section{Hasil dan Pembahasan}

Lokasi penelitian Hulu Sungai Opak oleh Djumanto \& Probosunu (2011) di wilayah Ngemplak dan Cangkringan sepanjang $1 \mathrm{~km}$. Lokasi penelitian kami di bagian hulu terdiri dari wilayah Cangkringan, Ngemplak, Kalasan dan Prambanan sepanjang 2,5 km (Tabel 1). Ikan Rasbora argyrotaenia (wader, rasbora, bada), Lepidocephalichthys hasseltii (uceng, sereni), Dermogenys pusilla (julung-julung), Channa gachua (kotes), dan Trichopodus trichopterus (sepat rawa) belum dijumpai pada penelitian sebelumnya, sehingga data ini dapat 
melengkapi data keanekaragaman ikan penelitian sebelumnya. Kelima jenis ikan yang dijumpai di tahun 2013 ini, merupakan ikan dengan persebaran alami berada di sungaisungai wilayah DIY.

Tabel 1. Lokasi area kajian di Sungai Opak dari Hulu, Tengah, Hilir hingga Muara.

\begin{tabular}{|c|c|c|}
\hline $\begin{array}{c}\text { Sungai } \\
\text { Opak }\end{array}$ & $\begin{array}{c}\text { Titik } \\
\text { Sampling } \\
\text { (TS) } \\
\end{array}$ & Nama Lokasi \\
\hline \multirow{5}{*}{ Hulu } & TS I & " Dusun Salam, Desa Wukirsari, Kecamatan Cangkringan, Kabupaten Sleman \\
\hline & TS II & $\begin{array}{l}\text { Dusun Panggung, Desa Argomulyo, Kecamatan Cangkringan, Kabupaten } \\
\text { Sleman }\end{array}$ \\
\hline & TS III & $\begin{array}{l}\text { Dusun Tambakan, Desa Sindumartani, Kecamatan Ngemplak, Kabupaten } \\
\text { Sleman }\end{array}$ \\
\hline & TS IV & $\begin{array}{l}\text { Dusun Sepatmadu, Desa Tamanmartani, Kecamatan Kalasan, Kabupaten } \\
\text { Sleman }\end{array}$ \\
\hline & TS V & Dusun Pulerejo, Desa Ngablak, Kecamatan Prambanan, Kabupaten Sleman \\
\hline \multirow{5}{*}{ Tengah } & TS I & Dusun Kowang, Desa Tamanmartani, Kecamatan Kalasan, Kabupaten Sleman \\
\hline & TS II & Dusun Mutihan, Desa Madurejo, Kecamatan Prambanan, Kabupaten Sleman \\
\hline & TS III & Dusun Sumberkidul, Desa Kalitirto, Kecamatan Berbah, Kabupaten Sleman \\
\hline & TS IV & Dusun Cikal, Desa Srimulyo, Kecamatan Piyungan, Kabupaten Bantul \\
\hline & TS V & Dusun Jlamprang, Desa Jambidan, Kecamatan Banguntapan, Kabupaten Bantul \\
\hline \multirow{5}{*}{ Hilir } & TS I & Dusun Kembangsongo, Desa Trimulyo, Kecamatan Jetis, Kabupaten Bantul \\
\hline & TS II & Dusun Bungas, Desa Sumberagung, Kecamatan Jetis, Kabupaten Bantul \\
\hline & TS III & Dusun Ledokgaten, Desa Canden, Kecamatan Jetis, Kabupaten Bantul \\
\hline & TS IV & Dusun Sraden, Desa Srihardono, Kecamatan Pundong, Kabupaten Bantul \\
\hline & TS V & Dusun Kalipakel, Desa Donotirto, Kecamatan Kretek, Kabupaten Bantul \\
\hline \multirow{4}{*}{ Muara } & TS I & Desa Parangtritis, Kecamatan Kretek (Pantai Depok), Kabupaten Bantul \\
\hline & TS II & Desa Parangtritis, Kecamatan Kretek (Pantai Depok), Kabupaten Bantul \\
\hline & TS III & Desa Trihargo, Kecamatan Kretek, Kabupaten Bantul \\
\hline & TS IV & Desa Trihargo, Kecamatan Kretek, Kabupaten Bantul \\
\hline
\end{tabular}

Pada penelitian ini, dari total 5 titik sampling didapatkan 9 spesies ikan (Tabel 2). Dari kesembilan spesies ikan tersebut, terdapat dua spesies ikan introduksi, yaitu: Poecilia reticulata dan Oreochromis niloticus. Ikan Poecilia reticulata persebaran alaminya di wilayah Venezuela, ikan ini diintroduksi sebagai ikan pembasmi nyamuk dan kemudian sebagai ikan hias akuarium (Lévêque, 1996; Colautti \& MacIsaac, 2004; Strauss, et al, 2006). Ikan Oreochromis niloticus diintroduksi dari Afrika ke hampir setiap negara sebagai ikan konsumsi. Masuknya kedua spesies ikan tersebut ke sungai-sungai kemungkinan besar karena dilepas secara sengaja, baik karena bosan, atau untuk kegiatan memancing dan dikonsumsi.

Lokasi penelitian di bagian tengah terdiri dari wilayah Kalasan, Prambanan, Berbah, Piyungan dan Banguntapan sepanjang 2,5 km (Tabel 1). Dari total 5 titik sampling didapatkan 19 spesies ikan (Tabel 3). Dari kesembilan belas spesies ikan tersebut, terdapat tiga spesies ikan introduksi, yaitu: Poecilia reticulata, Oreochromis niloticus dan Pterygoplichthys pardalis. Dua spesies ikan Poecilia reticulata dan Oreochromis niloticus juga dijumpai di bagian hulu. Kemungkinan besar kedua spesies ikan introduksi tersebut telah tersebar luas di Sungai Opak dari hulu hingga bagian tengah. Ikan Pterygoplichthys pardalis persebaran alaminya di Amerika Tengah seperti Kosta Rika dan Panama serta Amerika Selatan. Ikan sapu-sapu jenis Pterygoplichthys pardalis merupakan algivorus, sehingga jenis pakan spesifik ini membuatnya diminati banyak pecinta ikan ornamental untuk membersihkan akuarium mereka. Ikan sapu-sapu dijumpai di sungai, dimungkinkan karena mereka sengaja dibuang oleh pecinta ikan, ketika ukurannya besar dan tidak cukup lagi untuk akuarium atau terlepas dari pembudidayaan (Nelson, 2006; Hossain, 2018). 
Tabel 2. Jenis-jenis ikan dijumpai di bagian hulu Sungai Opak.

\begin{tabular}{|c|c|c|c|c|c|}
\hline \multirow[b]{2}{*}{ No. } & \multicolumn{3}{|c|}{ Ikan di bagian Hulu Sungai Opak } & \multicolumn{2}{|c|}{ Penelitian oleh } \\
\hline & Ordo & Familia & Spesies & $\begin{array}{c}\text { Donan dkk } \\
(2013)\end{array}$ & $\begin{array}{c}\text { Djumanto \& } \\
\text { Probosunu } \\
(\mathbf{2 0 1 1}) \\
\end{array}$ \\
\hline 1 & Cypriniformes & Cyprinidae & Barbodes binotatus & $\mathrm{V}$ & $\mathrm{V}$ \\
\hline 2 & Cypriniformes & Cyprinidae & Barbonymus gonionotus & - & $\mathrm{V}$ \\
\hline 3 & Cypriniformes & Cyprinidae & Rasbora argyrotaenia & $\mathrm{V}$ & - \\
\hline 4 & Cypriniformes & Balitoridae & Nemacheilus fasciatus & $\mathrm{V}$ & $\mathrm{V}$ \\
\hline 5 & Cypriniformes & Cobitidae & Lepidocephalichthys hasseltii & $\mathrm{V}$ & - \\
\hline 6 & Cyprinodontiformes & Poeciliidae & Poecilia reticulata* & $\mathrm{V}$ & $\mathrm{V}$ \\
\hline 7 & Cyprinodontiformes & Poeciliidae & Poecilia latipinna & - & $\mathrm{V}$ \\
\hline 8 & Cyprinodontiformes & Poeciliidae & Xiphophorus hellerii & - & $\mathrm{V}$ \\
\hline 9 & Beloniformes & Hemiramphidae & Dermogenys pusilla & $\mathrm{V}$ & - \\
\hline 10 & Perciformes & Channidae & Channa gachua & $\mathrm{V}$ & - \\
\hline 11 & Perciformes & Channidae & Channa striata & - & $\mathrm{V}$ \\
\hline 12 & Perciformes & Cichlidae & Oreochromis niloticus* & $\mathrm{V}$ & $\mathrm{V}$ \\
\hline 13 & Perciformes & Belontiidae & Trichopodus trichopterus & $\mathrm{V}$ & - \\
\hline 14 & Siluriformes & Clariidae & Clarias batrachus & - & $\mathrm{V}$ \\
\hline \multirow[t]{2}{*}{15} & Synbranchiformes & Synbranchidae & Monopterus albus & - & $\mathrm{V}$ \\
\hline & Jumlah & & & 9 & 10 \\
\hline
\end{tabular}

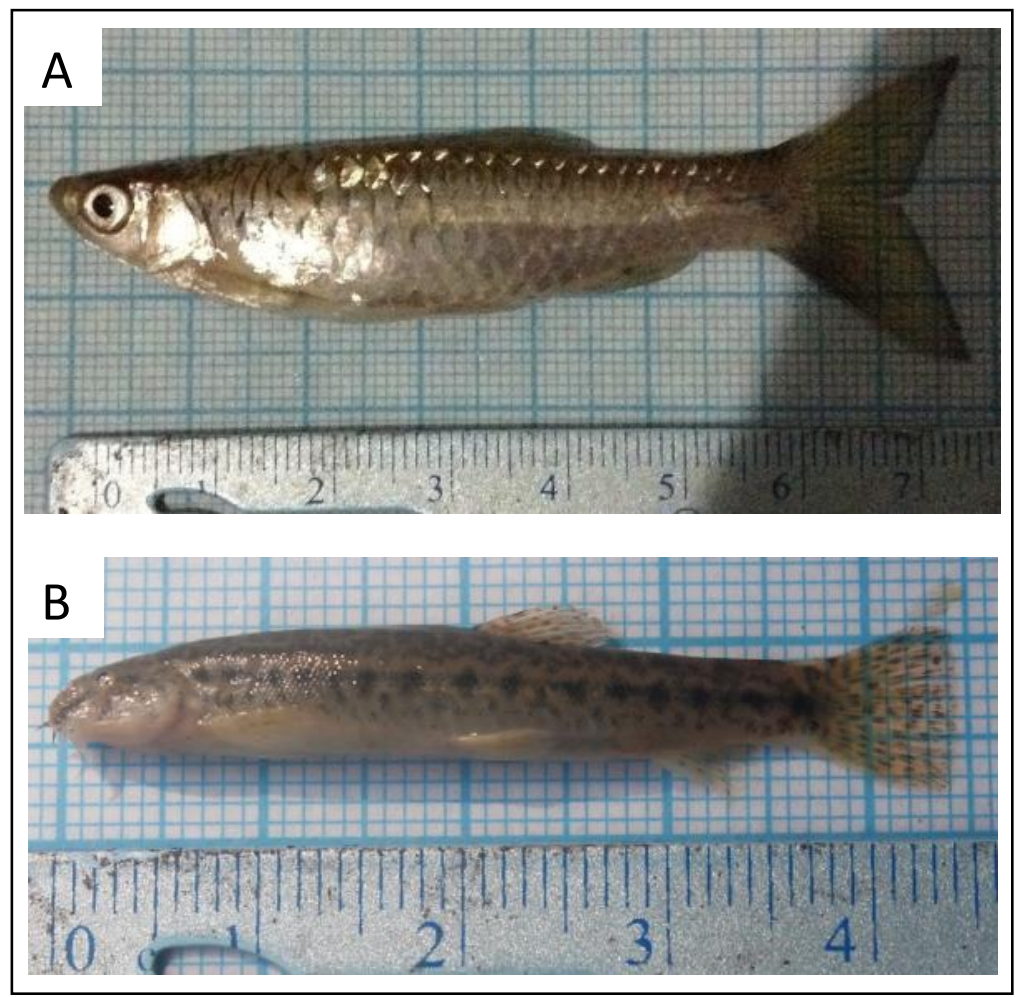

Gambar 1. Dua spesies ikan yang dijumpai di bagian hulu Sungai Opak tahun 2013: A) ikan Rasbora argyrotaenia (wader, rasbora, bada); B) ikan Lepidocephalichthys hasseltii (uceng, sereni). 
Tabel 3. Jenis-jenis ikan dijumpai di bagian Tengah Sungai Opak (Donan dkk, 2013)

\begin{tabular}{rlll}
\hline \hline \multirow{2}{*}{ No. } & \multicolumn{1}{c}{ Ordo } & \multicolumn{1}{c}{ Familia } & \multicolumn{1}{c}{ Spesies } \\
\cline { 2 - 4 } 1 & Cypriniformes & Cyprinidae & Barbodes binotatus \\
2 & Cypriniformes & Cyprinidae & Mystacoleucus obtusirostris \\
3 & Cypriniformes & Cyprinidae & Rasbora argyrotaenia \\
4 & Cypriniformes & Cyprinidae & Osteochilus vittatus \\
5 & Cypriniformes & Balitoridae & Nemacheilus fasciatus \\
6 & Cypriniformes & Cobitidae & Lepidocephalichthys hasseltii \\
7 & Cyprinodontiformes & Poeciliidae & Poecilia reticulata* \\
8 & Cyprinodontiformes & Aplocheilidae & Aplocheilus panchax \\
9 & Beloniformes & Hemiramphidae & Dermogenys pusilla \\
10 & Perciformes & Channidae & Channa gachua \\
11 & Perciformes & Channidae & Channa striata \\
12 & Perciformes & Cichlidae & Oreochromis niloticus* \\
13 & Perciformes & Belontiidae & Trichopodus trichopterus \\
14 & Siluriformes & Loricariidae & Pterygoplichthys pardalis* \\
15 & Siluriformes & Clariidae & Clarias batrachus \\
16 & Siluriformes & Clariidae & Clarias leiacanthus \\
17 & Siluriformes & Mastacembelidae & Hemibagrus nemurus \\
18 & Syngnathiformes & Macrognathus aculeatus \\
\hline \hline
\end{tabular}

* : introduksi

Berdasarkan data pada Tabel 3, tiga jenis ikan, yaitu: Ikan Mystacoleucus obtusirostris (wader kepek), Aplocheilus panchax (kepala timah), dan Clarias leiacanthus (lele), belum dijumpai pada penelitian sebelumnya (Trijoko dan Pranoto,
2006; Djumanto dan Probosunu, 2011; Djumanto et al., 2013) baik di bagian hulu maupun hilir. Data ketiga jenis ikan ini, dapat melengkapi data keanekaragaman ikan pada penelitian sebelumnya.

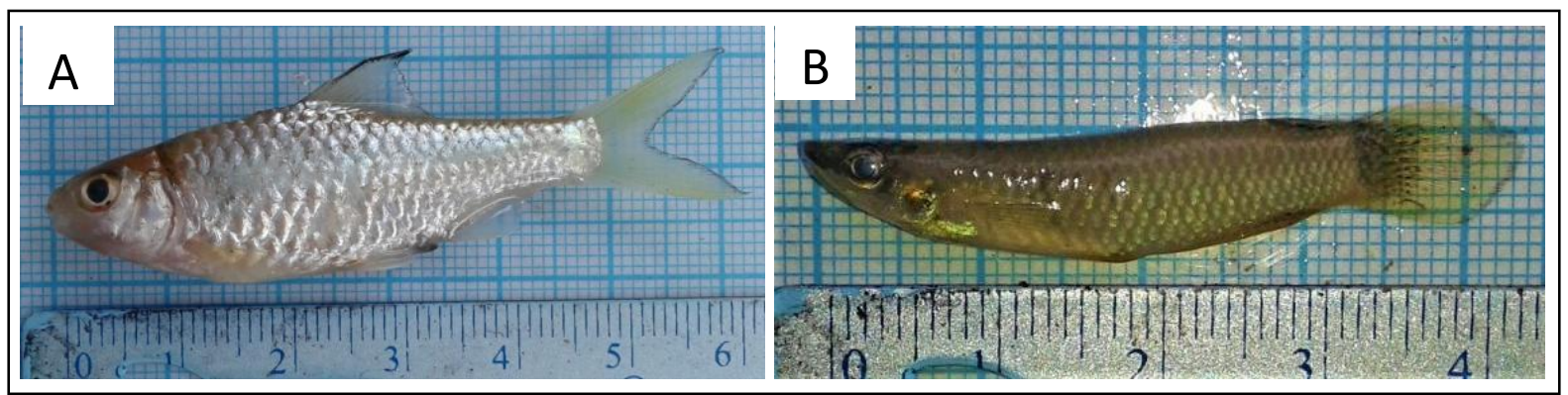

Gambar 2. Dua spesies ikan yang dijumpai dibagian tengah Sungai Opak tahun 2013: A) ikan Mystacoleucus obtusirostris (wader kepek); B) ikan Aplocheilus panchax (kepala timah).

Sampling di bagian Hilir Sungai Opak tahun 2013 juga dilakukan pada 5 titik sampling. Setiap titik sampling dilakukan pengambilan sampel siang dan malam hari. Dari total 5 titik sampling didapatkan 21 spesies ikan (Tabel 4). Dari 21 spesies ikan tersebut, terdapat tiga spesies ikan introduksi, yaitu: Poecilia reticulata, Oreochromis niloticus dan Pterygoplichthys pardalis. Dua spesies ikan Poecilia reticulata dan Oreochromis niloticus juga dijumpai di bagian hulu dan tengah. Sedangkan ikan Pterygoplichthys pardalis juga dijumpai di bagian tengah. Kemungkinan besar ketiga spesies ikan introduksi tersebut telah tersebar luas di Sungai Opak dari hulu hingga hilir. 
Tabel 4. Jenis-jenis ikan dijumpai di bagian Hilir Sungai Opak.

\begin{tabular}{|c|c|c|c|c|c|}
\hline \multirow[b]{2}{*}{ No. } & \multicolumn{3}{|c|}{ Ikan di bagian Hilir Sungai Opak } & \multicolumn{2}{|c|}{ Penelitian oleh } \\
\hline & Ordo & Familia & Spesies & Donan dkk (2013) & $\begin{array}{c}\text { Djumanto, Devi \& } \\
\text { Setyobudi (2013) }\end{array}$ \\
\hline 1 & Cypriniformes & Cyprinidae & Barbodes binotatus & $\mathrm{V}$ & $\mathrm{V}$ \\
\hline 2 & Cypriniformes & Cyprinidae & Systomus orphoides & - & $\mathrm{V}$ \\
\hline 3 & Cypriniformes & Cyprinidae & Barbonymus gonionotus & $\mathrm{V}$ & - \\
\hline 4 & Cypriniformes & Cyprinidae & Barbonymus schwanenfeldii & - & $\mathrm{V}$ \\
\hline 5 & Cypriniformes & Cyprinidae & Mystacoleucus obtusirostris & $\mathrm{V}$ & - \\
\hline 6 & Cypriniformes & Cyprinidae & Rasbora lateristriata & $\mathrm{V}$ & - \\
\hline 7 & Cypriniformes & Cyprinidae & Rasbora argyrotaenia & $\mathrm{V}$ & $\mathrm{V}$ \\
\hline 8 & Cypriniformes & Cyprinidae & Barbonymus balleroides & $\mathrm{V}$ & - \\
\hline 9 & Cypriniformes & Cyprinidae & Osteochilus vittatus & $\mathrm{V}$ & $\mathrm{V}$ \\
\hline 10 & Cypriniformes & Cyprinidae & Osteochilus melanopleura & - & $\mathrm{V}$ \\
\hline 11 & Cypriniformes & Cyprinidae & Hampala macrolepidota & V & $\mathrm{V}$ \\
\hline 12 & Cypriniformes & Carangidae & Caranx sexfasciatus & - & $\mathrm{V}$ \\
\hline 13 & Cypriniformes & Cobitidae & Lepidocephalichthys hasselti & - & $\mathrm{V}$ \\
\hline 14 & Cypriniformes & Balitoridae & Nemacheilus fasciatus & - & $\mathrm{V}$ \\
\hline 15 & Cypriniformes & Eleotridae & Eleotris melanosoma & V & $\mathrm{V}$ \\
\hline 16 & Cyprinodontiformes & Poeciliidae & Poecilia reticulata* & V & $\mathrm{V}$ \\
\hline 17 & Cyprinodontiformes & Aplocheilidae & Aplocheilus panchax & $\mathrm{V}$ & - \\
\hline 18 & Beloniformes & Hemiramphidae & Dermogenys pusilla & V & $\mathrm{V}$ \\
\hline 19 & Perciformes & Cichlidae & Oreochromis niloticus* & $\mathrm{V}$ & $\mathrm{V}$ \\
\hline 20 & Perciformes & Belontiidae & Trichopodus trichopterus & $\mathrm{V}$ & $\mathrm{V}$ \\
\hline 21 & Perciformes & Ambassidae & Ambassis vachelli & V & $\mathrm{V}$ \\
\hline 22 & Perciformes & Anabantidae & Anabas testudineus & - & $\mathrm{V}$ \\
\hline 23 & Perciformes & Channidae & Channa gachua & - & $\mathrm{V}$ \\
\hline 24 & Perciformes & Channidae & Channa striata & - & $\mathrm{V}$ \\
\hline 25 & Perciformes & Osphronemidae & Osphronemus goramy & - & $\mathrm{V}$ \\
\hline 26 & Perciformes & Rhyacichthyidae & Rhyacichthys aspro & - & V \\
\hline 27 & Perciformes & Gobiidae & Glossogobius circumpectus & - & $\mathrm{V}$ \\
\hline 28 & Perciformes & Gobiidae & Sicyopterus longifilis & - & $\mathrm{V}$ \\
\hline 29 & Perciformes & Lutjanidae & Lutjanus argentimaculatus & - & $\mathrm{V}$ \\
\hline 30 & Siluriformes & Loricariidae & Pterygoplichthys pardalis* & V & $\mathrm{V}$ \\
\hline 31 & Siluriformes & Bagridae & Hemibagrus nemurus & $\mathrm{V}$ & $\mathrm{V}$ \\
\hline 32 & Siluriformes & Bagridae & Hemibagrus planiceps & - & $\mathrm{V}$ \\
\hline 33 & Siluriformes & Clariidae & Clarias batrachus & - & $\mathrm{V}$ \\
\hline 34 & Synbranchiformes & Mastacembelidae & Macrognathus aculeatus & V & $\mathrm{V}$ \\
\hline 35 & Synbranchiformes & Synbranchidae & Monopterus albus & - & $\mathrm{V}$ \\
\hline 36 & Syngnathiformes & Syngnathidae & Microphis sp. & $\mathrm{V}$ & $\mathrm{V}$ \\
\hline 37 & Syngnathiformes & Syngnathidae & Microphis argulus & - & $\mathrm{V}$ \\
\hline 39 & Mugiliformes & Mugilidae & Osteomugil cunnesius & V & - \\
\hline 40 & Mugiliformes & Mugilidae & Mugil cephalus & - & $\mathrm{V}$ \\
\hline 41 & Anguilliformes & Moringuidae & Moringua raitaborua & V & - \\
\hline 42 & Anguilliformes & Anguillidae & Anguila marmorata & - & $\mathrm{V}$ \\
\hline & Jumlah & & & 21 & 35 \\
\hline
\end{tabular}

\footnotetext{
*: introduksi, diberi keterangan $\mathrm{V}=$ ditemukan
} 
Berdasarkan data pada Tabel 4, tujuh jenis ikan, yaitu: Ikan Barbonymus gonionotus, Mystacoleucus obtusirostris, Rasbora lateristriata, Barbonymus balleroides, Aplocheilus panchax, Osteomugil cunnesius, dan Moringua raitaborua belum dijumpai pada penelitian sebelumnya di bagian hilir (Djumanto et. al., 2013). Data ketujuh jenis ikan ini, dapat melengkapi data keanekaragaman ikan penelitian sebelumnya.

Terdapat tiga spesies ikan air payau demersal yang dijumpai di bagian hilir Sungai Opak, yaitu: Microphis sp., Osteomugil cunnesius, dan Moringua raitaborua. Ikan
Microphis adalah ikan yang hidup secara anadromus. Dilihat dari ukurannya, ikan Microphis termasuk kategori remaja, sehingga dimungkinkan baru saja menetas dan akan menuju ke laut. Kemudian ikan Osteomugil cunnesius ikan yang hidup secara katadromus. Jika dilihat dari ukurannya ikan Osteomugil cunnesius berukuran dewasa, sehingga memang dijumpai di perairan payau seperti hilir dan muara sungai. Mengenai ikan Moringua raitaborua merupakan ikan perairan tawar dan payau yang hidup demersal, keberadaannya di bagian hilir sungai adalah sesuai dengan habitat alaminya.

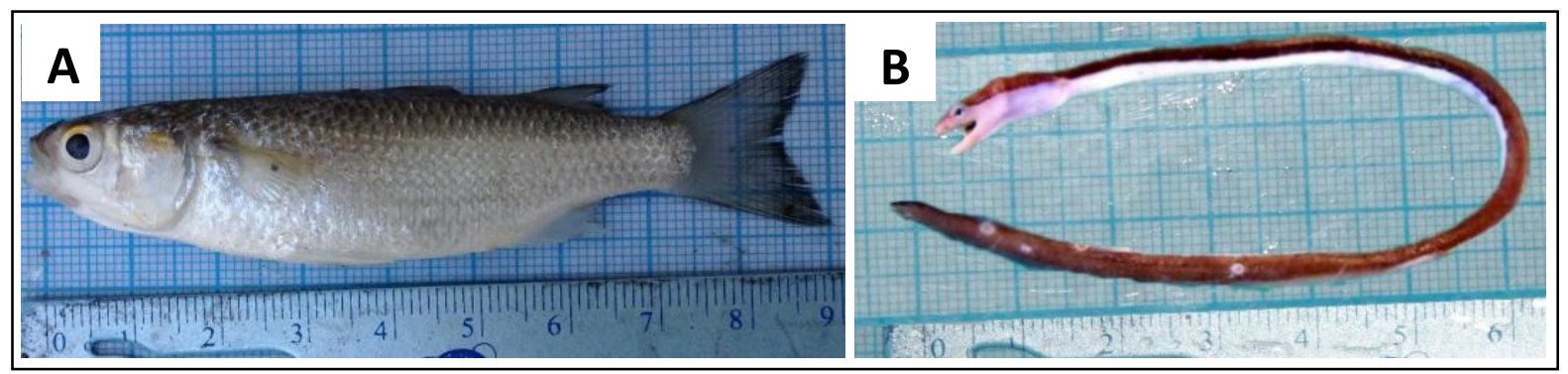

Gambar 3. Dua spesies ikan yang dijumpai dibagian hilir Sungai Opak tahun 2013: A) ikan Osteomugil cunnesius; B) ikan Moringua raitaborua.

Tiga jenis ikan introduksi dibagian hilir sangat melimpah, mungkin karena mudahnya mereka berkembang biak. Selain itu, kondisi badan air di hilir sungai yang luas dan dalam merupakan faktor mudahnya populasi mereka meledak. Keanekaragaman spesies ikan di bagian hilir Sungai Opak lebih tinggi daripada di hulu. Hal tersebut dikarenakan hilir sungai juga menjadi habitat bagi beberapa spesies ikan diadromus, baik anadromus, katadromus, maupun amfidromus seperti Osteomugil cunnesius dan Moringua raitaborua yang merupakan ikan katadromus serta Microphis yang merupakan ikan amfidromus (Mennesson, et al., 2015; Engman, et al., 2018; McBridge \& Matheson 2011; Milton, 2009).

Sampling di bagian Muara Sungai Opak hanya dilakukan pada 4 titik sampling. Setiap titik sampling dilakukan pengambilan sampel siang dan malam hari. Penentuan empat titik sampling karena bentuk muara sungai yang setengah lingkaran, sehingga diputuskan dua titik pada masing-masing setengah sisinya. Dari total 4 titik sampling didapatkan 20 spesies ikan (Tabel 5).

Berdasarkan data pada Tabel 5, lima belas jenis ikan yang dijumpai di muara sungai, yaitu: Thynnichthys thynnoides, Caranx ignobilis, Ophiocara porocephala, Glossogobius giuris, Gobiopterus brachypterus, Pseudogobius javanicus, Pseudogobiopsis sp., Gerres filamentosus, Terapon jarbua, Lutjanus russelli, Gazza minuta, Achiroides leucorhynchos, Cynoglossus puncticeps, Chelonodon patoca, dan Stolephorus commersonii hanya dijumpai di penelitian tahun 2013.

Dua ikan laut dan payau yang dijumpai di muara Sungai Opak, yaitu Caranx ignobilis dan Terapon jarbua. Ikan Caranx ignobilis adalah ikan laut yang hidup di laut kawasan sedang dan tropis. Ikan ini merupakan bahan makanan penting dan sering dipancing. Caranx ignobilis sering berada di laguna atau muara sungai terutama anakan (Carpenter and Niem, 1999). Sedangkan ikan Terapon jarbua adalah ikan laut yang hidup di seluruh kawasan IndoPasifik dan kadang memasuki muara sungai dan perairan tawar. Ikan ini menyukai habitat muara sungai dengan dasar berpasir dan dangkal. Anakan (juvenile) spesies ini memiliki pola warna tubuh yang atraktif sehingga sering dijadikan ikan peliharaan ornamental (Gupta \& Banarjee, 2016). 
Tabel 5. Jenis-jenis ikan dijumpai di bagian Muara Sungai Opak tahun 2013.

\begin{tabular}{rlll}
\hline \hline No. & \multicolumn{1}{c}{ Familia } & \multicolumn{1}{c}{ Ikan di bagian Muara Sungai Opak } \\
\hline \hline 1. & Cyprinidae & Rasbora argyrotaenia & \multicolumn{1}{c}{ Nama lokal } \\
2. & & Thynnichthys thynnoides & Wader, rasbora, bada \\
3. & Ambassidae & Ambassis vachelli & Cemara \\
4. & Carangidae & Caranx ignobilis & Wader ayu \\
5. & Eleotridae & Eleotris melanosoma & Kuwe \\
6. & & Ophiocara porocephala & Gabus \\
7. & Gobiidae & Glossogobius giuris & Lontok, payangka \\
8. & & Gobiopterus brachypterus & Bloso, nyereh \\
9. & Bagridae & Hemibagrus nemurus & Lempuk \\
10. & Mugilidae & Osteomugil cunnesius & Baung \\
11. & Soleidae & Achiroides leucorhynchos & Belanak \\
12. & Tetraodontidae & Chelonodon patoca & Sebelah \\
13. & Gerreidae & Gerres filamentosus & Sumben \\
14. & Teraponidae & Terapon jarbua & Kapasan \\
15. & Pseudochromidae & Pseudogobius javanicus & Kerong-kerong \\
16. & & Pseudogobiopsis sp. & Bloso \\
17. & Engraulididae & Stolephorus commersonii & Bloso \\
18. & Cynoglossidae & Cynoglossus puncticeps & Teri \\
19. & Lutjanidae & Lutjanus russelli & Lidah \\
20. & Leiognathidae & Gazza minuta & Kakap, keukirong \\
\hline \hline
\end{tabular}

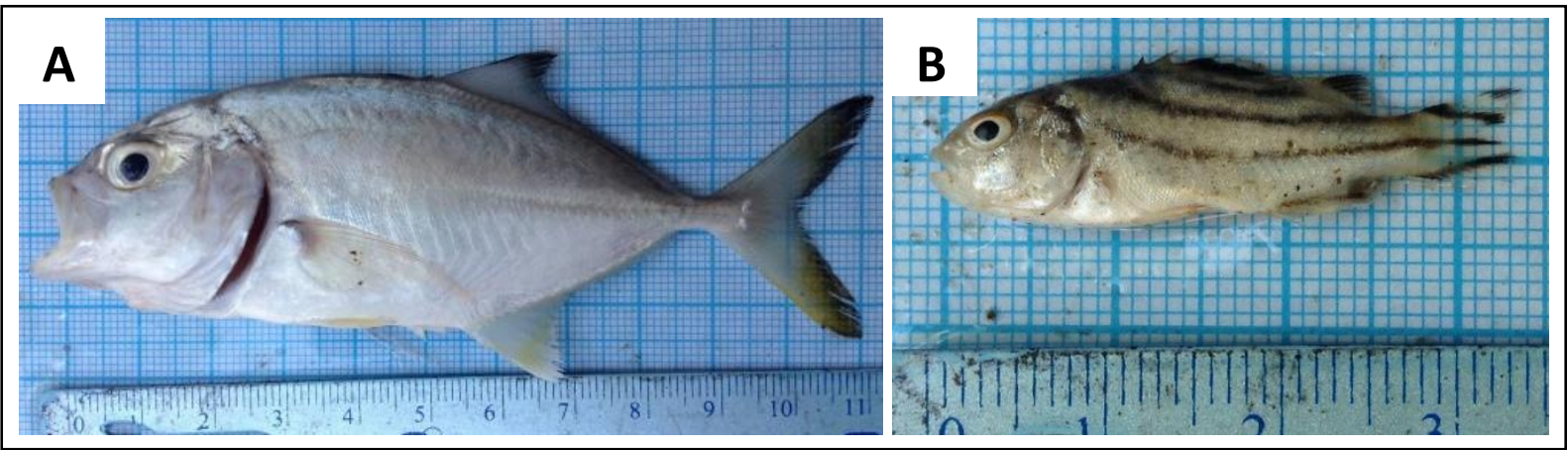

Gambar 4. Dua spesies ikan laut yang dijumpai di bagian muara Sungai Opak: A) ikan Caranx ignobilis; B) ikan Terapon jarbua. Keduanya merupakan ikan perairan payau dan laut.

Pada bagian muara dijumpai juga dua spesies ikan anggota ordo Pleuronectiformes, yaitu Cynoglossus puncticeps dan Achiroides leucorhynchos. Kedua spesies ikan tersebut kesemuanya memiliki kesamaan yaitu tubuh pipih dan kedua mata berada di satu sisi badan, tetapi keduanya terbagi ke dalam dua kelompok takson tingkat familia yang berbeda, yaitu Cynoglossus puncticeps masuk ke dalam familia Cynoglossidae sedangkan Achiroides leucorhynchos masuk ke dalam familia Soleidae.
Karakter diagnostik ikan Cynoglossus puncticeps adalah: pada kepala terdapat bercak-bercak besar, bercak tersebut kadang bersatu membentuk pita melintang tidak teratur; beberapa jari-jari sirip punggung dan sirip dubur berwarna coklat; sirip ekor dengan 10 jari-jari; gurat sisi dipisahkan oleh 16-19 sisik; sudut mulut lebih dekat ke ujung moncong daripada ke arah celah insang. Karakter diagnostik ikan Achiroides leucorhynchos adalah: tidak ada tanda hitam di sekitar mulut pada sisi tanpa mata. 
Keanekaragaman spesies ikan di muara Sungai Opak lebih tinggi daripada di hulu tetapi sama dengan di bagian tengah dan hilir. Ikan-ikan di muara Sungai Opak di dominasi oleh jenis-jenis ikan air payau dan air laut, serta ikan-ikan diadromus. Beberapa jenis ikan diadromus yang dijumpai di muara Sungai Opak seperti Terapon jarbua yang merupakan ikan katadromus; Chelonodon patoca dan
Stolephorus commersonii yang merupakan ikan anadromus; serta Achiroides leucorhynchos, Gerres filamentosus, Pseudogobius javanicus, Pseudogobiopsis sp., Cynoglossus puncticeps, Lutjanus russelli, dan Gazza minuta yang merupakan ikan amfidromus (Mennesson, et al, 2015; Engman, et al, 2018; McBridge \& Matheson 2011; Milton, 2009).

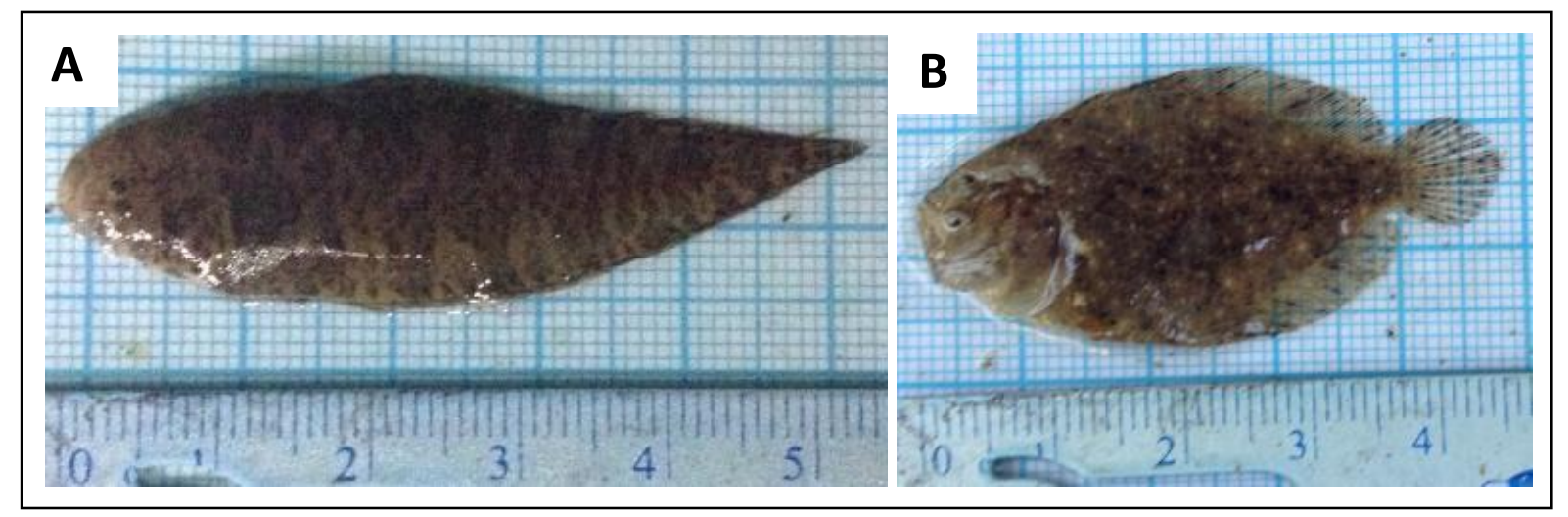

Gambar 5. Dua spesies ikan sebelah (Pleuronectiformes) yang dijumpai di bagian muara Sungai Opak: a) ikan Cynoglossus puncticeps; b) ikan Achiroides leucorhynchos, keduanya merupakan ikan demersal di perairan payau \& laut.

\section{Simpulan}

Terdapat beberapa jenis ikan yang tidak dijumpai pada penelitian sebelumnya, yaitu: lima jenis ikan di bagian hulu, di bagian tengah terdapat tiga jenis ikan yang tidak dijumpai pada penelitian sebelumnya, baik sampling hulu maupun hilir. Di bagian hilir dijumpai tujuh jenis ikan saat penelitian tahun 2013 dan tidak dijumpai pada penelitian sebelumnya. Pada bagian muara, dijumpai lima belas jenis ikan yang tidak dijumpai di hilir pada penelitian sebelumnya. Total terdapat 28 jenis ikan yang dijumpai di tahun 2013 tetapi belum dijumpai di penelitian sebelumnya.

Perlu dilakukan sampling pada musim hujan guna membandingkan data keanekaragaman dengan data penelitian ini. Penggunaan electric fishing diperlukan karena mampu untuk mendapatkan spesies ikan yang lebih lengkap. Penggunaan electric fishing harus melalui proses ethical clearance (kelayakan etik) yang diajukan ke Komisi Etik dahulu sebelum digunakan. Jika sudah mendapatkan kelayakan etik, selanjutnya perijinan penggunaan electric fishing ke Bappeda Propinsi hingga Kabupaten dan
Kepolisian setempat dengan pengantar ijin penelitian dari institusi akademik.

\section{Ucapan Terima Kasih}

Terima kasih disampaikan kepada Fakultas Biologi UGM yang telah memberikan dana penelitian melalui BOPTN Fakultas tahun 2013, Seluruh staf dan asisten di Laboratorium Sistematika Hewan serta anggota tim peneliti yang telah banyak memberikan waktu untuk diskusi dan ijin kerja di laboratorium.

\section{Daftar Pustaka}

Carpenter, K.E. and Niem, V.H. 1999. (eds) FAO species identification guide for fishery purposes. The living marine resources of the Western Central Pacific. Volume 4. Bony fishes Part 2 (Mugilidae to Carangidae). Rome, FAO. pp. 2712.

Chaklader, R.Md., A. Nahar, M.A.B. Siddik, and R. Sharker. 2014. Feeding Habits and Diet Composition of Asian Catfish Mystus vittatus (Bloch, 1794) in Shallow Water of an Impacted Coastal Habitat. World Journal of Fish and Marine Sciences 6 (6): 551-556. 
Colautti, R.I., and H.J. MacIsaac. 2004. A neutral terminology to define invasive' species. BIODIVERSITY RESEARCH, Diversity and Distributions, (Diversity Distrib.) (2004) 10, 135-141.

Djumanto dan N. Probosunu. 2011. Biodiversitas sumber daya ikan di hulu Sungai Opak. Jurnal Iktiologi Indonesia, 11(1):1-10.

Djumanto, M.I.P. Devi dan E. Setyobudi. 2013. Ichthyofauna distribution in downstream region of Opak River, Yogyakarta. Jurnal Iktiologi Indonesia, 13(2):97-108.

Engman, A.C., Thomas J.K, and W.G. Cope. 2018. Do postlarval amphidromous fishes transport marine-derived nutrients \& pollutans to Caribben streams? Article, Wiley Ecology of Freshwater Fish. Vol. 27, Issue 3. Published by John Wiley \& Sons Ltd. pp. 847.

Gupta, S. and S. Banarjee. 2016. A Short Review on the Biology of Tiger Perch, Terapon jarbua (Forsskål, 1775). Review Article. International Journal of Research in Fisheries and Aquaculture 6(2): 79-83.

Hossain, M.Y., Robert L.V. Jr., R. Ruiz-Carus, and S.M. Galib. 2018. Amazon Sailfin Catfish Pterygoplichthys pardalis (Loricariidae) in Bangladesh: A Critical Review of Its Invasive Threat to Native and Endemic Aquatic Species. Fishes 2018, 3, 14; doi:10.3390/fishes3010014. MDPI. pp.1-12.

Karr J.R., P.L Angermeier., and I.J Schlosser. 1983. Habitat structure and fish communities of warmwater streams. Environmental Protection Agency. Corvallis.

Kottelat, M. 2013. The Fishes of the Inland Waters of Southeast Asia: A Catalogue and Core Bibliography of the Fishes Known to Occur in Freshwaters, Mangroves and Estuaries. The Raffles Bulletin of Zoology. An International Journal of Southeast Asian Zoology. Supplement No. 27.

Kottelat, M., A.J. Whitten, S.N. Kartikasari and S. Wirjoatmodjo. 1993. Fresh Water Fishes of Western Indonesia and Sulawesi. Periplus Editions Limited, Jakarta. Pp. 75; 82; 85-86; 91-92; 107 $108 ; 149-150 ; 153 ; 234-235 ; 236-237$.
Lévêque, C. 1996. Chapter 38. Introduction of Fish Species in Freshwater: A Major Threat to Aquatic Biodiversity? In Biodiversity, Science and Development, Towards a New Partnership. Edited by: Francesco di Castri and Talal Younès. Cab International in association with the International Union of Biological Sciences. Pp. 446-451.

McBride, R., and R.E. Matheson. 2011. Florida's diadromous fishes: biology, ecology, management \& conservation. Biological Sciences. Florida Scientist. Vol. 74, No. 3. pp. 187.

Mennesson, M.I., H. Tabouret, C. Pecheyran, E. Feunteun and P. Keith. 2015. Amphidromous life cycle of Eleotris fusca (Gobioidei: Eleotridae), a widespread species from the IndoPacific studied by otolith analyses. Cybium 2015, 39(4): 249-260.

Milton, D.A., 2009. Chapter 9. Living in Two Worlds: Diadromous Fishes, and Factors Affecting Population. Nagelkerken, Ivan (ed.), Ecological Connectivity among Tropical Coastal Ecosystems. Springer Science+Business Media B.V. pp. 326.

Mohsin, M.A.K., and M.A. Ambak. 1983. Freshwater Fishes of Peninsular Malaysia. Penerbit Universiti Pertanian Malaysia.

Nelson, J.S., 1984. Fishes of the World. $2^{\text {nd }}$ ed. A Wiley-Interscience Publication. John Wiley dan Sons. Pp. 124-125, 153, 214-215.

Nelson, J.S., 2006. Fishes of the World. $4^{\text {nd }}$ ed. A Wiley-Interscience Publication. John Wiley dan Sons. Pp. 170-171.

Nelson, J.S., T.C. Grande, and M.V.H. Wilson. 2016. Fishes of the World. $5^{\text {th }}$ ed. John Wiley dan Sons. Pp. 139, 149, 152, 180, 181, 190, 191, 207, 216, 222, 230, $341,342,363,366,380,381,430$.

Phukon, H. dan S.P. Biswas. 2011. Investigation on Channa gachua as a Potential Biological Control Agent of Musquitoes under Laboratory Conditions. Asian Journal of Biological Science. Vol. 2 (4).

Prakoso, V.A., M.H.F. Ath-thar, J. Subagja, dan A.H. Kristanto. 2016. Pertumbuhan Ikan Uceng (Nemacheilus fasciatus) 
dengan Padat Tebar Berbeda Dalam Lingkungan Ex Situ. Jurnal Riset Akuakultur, 11 (4), 2016, 355-36.

Rachmatika, I., 2003. Fish Fauna of The Gunung Halimun National Park, West Java. Biodiversity Conservation Project, LIPI, JICA, PHKA. Binamitra, Jakarta Indonesia.

Rahmadhiany, H.D., 2010. Keanekaragaman Jenis Ikan di Muara Sungai Progo, Kabupaten Kulon Progo, Daerah Istimewa Yogyakarta. Seminar. Fakultas Biologi. Universitas Gadjah Mada.

Rainboth, W.J. 1996. Fishes of the Cambodian Mekong. FAO species identification field guide for fishery purposes. Rome, FAO. Pp. 137.

Reznick, D.N., dan H.A. Bryga. 1996. Life-history Evolution in Guppies (Poecilia reticulata: Poecilidae). V. Genetic Basis of Parallelism in Life Histories. The American Naturalist Vol. 147, No. 3, pp. 339-359. The University of Chicago Press.

Siradz, S.A., E.S. Harsono, dan I. Purba. 2008. Kualitas Air Code, Winongo dan Gajahwong, Daerah Istimewa Yogyakarta. Jurnal Ilmu Tanah dan Lingkungan Vol.8, No.2. Pp.121 - 125.
Stiati, F., 2000. Keanekaragaman dan Distribusi Ikan di Sungai Opak, Kabupaten Bantul, Daerah Istimewa Yogyakarta. Seminar. Fakultas Biologi. Universitas Gadjah Mada. Yogyakarta.

Strauss, S.Y., C.O. Webb, and N. Salamin. 2006. Exotic taxa less related to native species are more invasive. PNAS, April 11, 2006, vol. 103, no. 15. Pp. 5841-5845

Trijoko \& FX. Sugiyo Pranoto. 2006. Keanekaragaman Jenis Ikan di Sepanjang Aliran Sungai Opak Daerah Istimewa Yogyakarta. Prosiding Seminar Nasional Ikan IV (29-30 Agustus 2006). Jatiluhur. Hal. 293-300.

Trijoko \& D.S. Yudha, R Eprilurahman dan S.S. Pambudi. 2016. Keanekaragaman jenis ikan di sepanjang Sungai BoyongCode Propinsi Daerah Istimewa Yogyakarta. Journal of Tropical Biodiversity and Biotechnology. Vol. 1, Issue 1. Pp. 21-29. 